\title{
Freezing Treatments for Ectomyelois ceratoniae Mortality and Maintenance of Deglet Noor Palm Date Quality
}

\author{
Rihab Ben-Amor, ${ }^{1,2}$ María Dolores de Miguel-Gómez, ${ }^{2}$ Dhouibi Mohamed Habib, ${ }^{3}$ \\ Hermi Nouha, ${ }^{3}$ and Encarna Aguayo (iD ${ }^{1,4}$ \\ ${ }^{1}$ Postharvest and Refrigeration Group, Universidad Politécnica de Cartagena (UPCT), Paseo Alfonso XIII, 48, 30203 Cartagena, \\ Murcia, Spain \\ ${ }^{2}$ Department of Business Economic, UPCT, Murcia, Spain \\ ${ }^{3}$ Department of Plant Protection: Laboratory of Entomology, National Institute of Agronomy of Tunisia, Tunis, Tunisia \\ ${ }^{4}$ Institute of Plant Biotechnology, UPCT, Plaza del Hospital s/n, 10 Campus Muralla del Mar, 30202 Cartagena, Murcia, Spain \\ Correspondence should be addressed to Encarna Aguayo; encarna.aguayo@upct.es
}

Received 1 February 2019; Revised 5 April 2019; Accepted 16 April 2019; Published 13 May 2019

Academic Editor: Francisca Hernández

Copyright ( 2019 Rihab Ben-Amor et al. This is an open access article distributed under the Creative Commons Attribution License, which permits unrestricted use, distribution, and reproduction in any medium, provided the original work is properly cited.

\begin{abstract}
Background. Insect infestation caused by Ectomyelois ceratoniae or carob moth is one of the main postharvest problems that can lead to a decrease of the marketable quality of dates. The control of carob moth is a mandatory process for exported fruits, and the main chemical method used to prevent pest diseases of palm date is treatment with methyl bromide. However, its use is being restricted due to direct harmful effects on the environment and indirect effects on humans. Freezing treatments could be physical alternatives to methyl bromide and other chemicals. Three freezing treatments at $-18^{\circ} \mathrm{C}(50 \mathrm{~h}, 77 \mathrm{~h}$, and $125 \mathrm{~h})$ were studied for $E$. ceratoniae mortality in Deglet Noor date fruits. Results. The results showed that freezing at $-18^{\circ} \mathrm{C}$ led to $100 \%$ mortality of all the stages of E. ceratoniae found in naturally infested dates. Fruit quality was examined under a selected sanitizing freezing treatment $\left(50\right.$ hours at $-18^{\circ} \mathrm{C}$ ). This freezing treatment induced an increase of monosaccharides and a reduction in antioxidant activity (40 to $45 \%$, measured with FRAP and DPPH assays). However, other parameters such as color, amino acids, total phenolic content, and microbial and sensorial quality were not affected by that treatment. All samples remained above the limit of marketability as there was no chilling injury. Conclusion. This treatment can be recommended as a green alternative to chemical treatments to control carob moth while yielding optimum-quality Deglet Noor date fruits that could be exported to developed countries.
\end{abstract}

\section{Introduction}

Date palm (Phoenix dactylifera L.) is the main fruit crop in arid and semiarid regions of western Asia and North Africa between $24^{\circ} \mathrm{N}$ and $34^{\circ} \mathrm{N}$ [1]. Tunisia and Algeria are the traditional Deglet Noor cultivar suppliers for Europe [2]. This native cultivar is the most popular because of its large size, texture, and distinctive taste and color, which gives it a high commercial value [3] and accounts about $80 \%$ of the production. In contrast, common cultivars are less appreciated and account for approximately $20 \%$ of the production of Tunisia dates [4].

The main problem in the production, storage, marketing, and exporting of date fruits generally is the loss caused by insect infestation [5]. Particularly in Tunisia, the carob moth, Ectomyelois ceratoniae Zeller, is a major insect pest of dates, pomegranate, and several other host plants [6]. This pest causes great economics losses, and the yearly infestation rate can reach $20 \%$ of harvestable dates in Tunisia [7]. It decreases the marketable quality of dates and risks compromising exports, especially those of Deglet Noor cultivar [8].

Methyl bromide, which is being used in many countries, is very effective for controlling insects in stored dates [9]. However, it is an ozone depleting substance, and according to the Montreal Protocol, developed countries were expected to phase methyl bromide out by 2005, while developing countries were expected to phase it out by 2015 [10]. Hence, physical treatments alternatives are needed urgently. 
The use of cold temperatures for the managing of stored products can be an important component of insect pest management programs [11]. Since cold temperatures directly affect the spread and impact of invasive pests [12], depending of the geographic zone, insects can be regularly exposed to potentially lethal freezing conditions [13]. Most insects require only a short exposure to very low temperatures $\left(-15^{\circ} \mathrm{C}\right.$ or below) to ensure control [14]. At subzero temperatures, insects risk freezing of their body fluids, as well as a host of other low temperature-related injuries [15]. As for fruit quality under freezing conditions, BarbosaCánovas et al. [16] indicated that this method is one of the few that allows for the preservation of food attributes such as taste and texture whilst maintaining the nutritional value, with this retention of quality better achieved when foods were kept at $-18^{\circ} \mathrm{C}$ or even lower temperatures. At these temperatures, micro-organisms cannot grow and any fooddeterioration processes take place at very slow rates.

Therefore, the aim of the current work was to find the minimum length of time at $-18^{\circ} \mathrm{C}$ needed that would induce Ectomyelois ceratoniae mortality and to know the effects of this treatment on fruit quality.

\section{Materials and Methods}

2.1. Chemicals. Ultrapure water was obtained from a Milli-Q system (Academic Gradient A10, Millipak ${ }^{\mathrm{TM}}$ 40, Millipore, París, France). Sodium hydroxide and methanol (HPLC grade) were purchased from Panreac Química S.A. (Castellar del Vallés, Barcelona, Spain). Individual amino acids and sugars, hydrochloric acid (minimum 37\%), sodium chloride, methanol, sodium sulfate, DPPH (2,2-diphenyl-1-picrylhydrazyl radical), gallic acid (3,4,5-trihydroxybenzoic acid), and FolinCiocalteu's phenol reagent were purchased from Sigma-Aldrich Química S.A. (Madrid, Spain). Peptone water, plate count, and rose bengal were from Scharlau (Barcelona, Spain).

\subsection{Experiment 1: Ectomyelois ceratoniae Mortality under Different Freezing Treatments}

2.2.1. Plant and Entomological Material. Deglet Noor cv. dates that were naturally infested with E. ceratoniae of date palm (Phoenix dactylifera L.) were collected at the beginning of November from an experimental palm orchard $\left(33^{\circ} 55^{\prime} 0^{\prime \prime}\right.$ North, $8^{\circ} 8^{\prime} 0^{\prime \prime}$ East), belonging to the National Institute of Agronomy of Tunisia located in Tozeur (South west, Tunisia). Naturally-infested dates are characterized by the presence of silk closing the calyx. These fruits were at the fully mature "Tamar" stage and were carefully collected by professional entomologists from the Department of Plant Protection (National Institute of Agronomy of Tunisia) and used to study the effect of freezing treatment on E. ceratoniae mortality.

For insect mortality studies, three different freezing treatments were applied based on the recommendations of Kader and Hussein [17]. These authors suggested freezing at $-18^{\circ} \mathrm{C}$ or lower for at least $48 \mathrm{~h}$ (from the time when the fruit temperature reaches $-18^{\circ} \mathrm{C}$ or lower) is enough to kill all life stages of stored products insects. In our experiment, we worked using three different lengths time at $-18^{\circ} \mathrm{C}$, with 50 ,
77 , and $125 \mathrm{~h}$ being the actual duration of each freezing treatment at that temperature. Untreated date palm fruits were used as the control, and these were placed in a chamber at room temperature. All of these treatments were carried out on three bunches of 100 naturally-infested dates, for a total of 300 dates per treatment. Those bunches were placed in plastic bags in different positions inside a freezing chamber, which was designed for the treatment of exported dates.

The development stages of E. ceratoniae present inside the fruit were mainly larvae (young larvae: $\mathrm{L}_{1}, \mathrm{~L}_{2}$, and $\mathrm{L}_{3}$ and old larvae: $\mathrm{L}_{4}$ and $\mathrm{L}_{5}$ ), pupae and other pests, and feces and webbings of larvae. The finding of infestation by different insect stages is representative of a normal date fruit sample. Date infestation rates varied between 53 and 78\% (Table 1).

2.2.2. Equipment. The freezing treatments were conducted in a chamber with a $140 \mathrm{~m}^{3}$ freezer system. Temperature $\left({ }^{\circ} \mathrm{C}\right)$ and relative humidity $(\% \mathrm{RH})$ inside the freezing chamber were measured using hygro buttons (Button, Mytec, Tunisia). Temperature $\left({ }^{\circ} \mathrm{C}\right)$ was recorded by placing nine thermo buttons (Button, Mytec, Tunisia) in different places inside the chamber.

2.2.3. Insect Mortality. To calculate E. ceratoniae mortality, live and dead insects were manually counted and examined with a binocular microscope. The total numbers of live and dead insects were used to calculate the percentage of mortality.

\subsection{Experiment 2: Overall Date Fruit Quality after Treating} with the Temperature That Caused 100\% Mortality of Ectomyelois ceratoniae. Once the shortest freezing treatment that resulted in $100 \%$ Ectomyelois ceratoniae mortality was known, noninfested date fruits were subjected to the same treatment to evaluate its effect on fruit quality.

2.3.1. Plant Material. Noninfested date fruits, Deglet Noor $\mathrm{cv}$., were harvested at the fully mature "Tamar" stage from a commercial farm located in an Oasis in southern Tunisia (Tozeur). Professional pickers detached the date bunches from the head of the palm tree, and these were carefully placed on the ground by hand to avoid crushing and the abscission of dates. These bunches were then cut into spikelets and placed in boxes. About $50 \mathrm{~kg}$ of spikelets were placed in polystyrene boxes and transported about $500 \mathrm{~km}$ by car to Tunis, then by plane to Madrid (Spain), and again by car about $400 \mathrm{~km}$ to the Pilot Plant of the Technical University of Cartagena. Total transport duration was about $7 \mathrm{~d}$ at $8^{\circ} \mathrm{C}$. After arrival, a visual inspection and selection was performed to remove damaged dates. The average weight was $12.1 \pm 1.5 \mathrm{~g}$, length $44.91 \pm 0.52 \mathrm{~mm}$, and thickness $21.91 \pm 0.48 \mathrm{~mm}$. The fruit moisture content was $25 \%$. Samples of $180 \mathrm{~g}$ of date fruits ( $\approx 15$ fruits) were placed in $1 \mathrm{~L}$ polypropylene trays (Barket, Befor Model, Chassieu, France), and the borders were heat sealed with a $35 \mu \mathrm{m}$ thick microperforated oriented polypropylene film (OPP) 


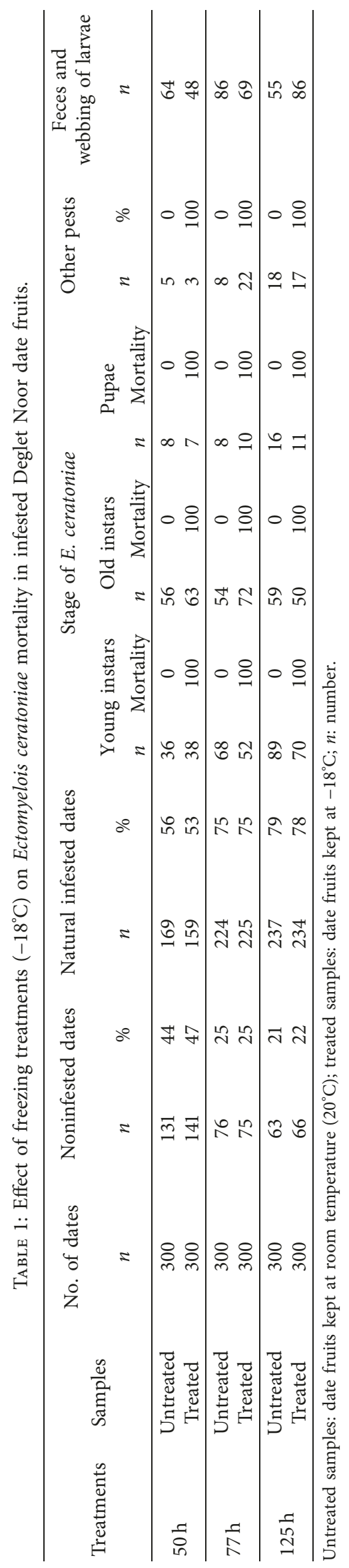


(Danisco Flexible, Bristol, UK). Samples (trays) were classified into two uniform groups: control date fruits were stored for $72 \mathrm{~h}$ in a chamber at room temperature $\left(20^{\circ} \mathrm{C} \pm 2^{\circ} \mathrm{C}\right)$ and frozen treatment kept at $-18^{\circ} \mathrm{C}$ for 50 hours $(72 \mathrm{~h}$ for the total freezing and thawing processes). Three replicates (trays) from each treatment were used, and the evaluation of quality was performed at day 0 (initial) and after 3 days at room temperature or at the end of the freezing storage process. After that time, frozen date fruits were removed from the freezer and kept at room temperature until they were completely thawed before quality analysis.

\subsubsection{Quality Parameters}

(1) Physical Measurements Color. The date peel's external color was determined on three random sides of dates. A color-difference meter (Minolta CR 300, Ramsey, NJ, USA) was used ( $\mathrm{C}$ standard C.I.E. illumination, $0^{\circ}$ viewing), and the results were expressed as $\operatorname{CIE} L^{*} a^{*} b^{*}$ color space units. $L^{*}$ defines the lightness and $a^{*}$ and $b^{*}$ define the red-greenness and blue-yellowness, respectively. The color was also expressed as hue angle $\left(h^{\circ}=\operatorname{arctangent}\left[\left(b^{*}\right) \cdot\left(a^{*}\right)^{-1}\right]\right)$ and chroma $\left(C^{*}=\left[\left(a^{*}\right)^{2}+\left(b^{*}\right)^{2}\right]^{1 / 2}\right)$.

Firmness. It was determined on the two flat sides of each date piece by means of a texturometer (Ibertest, Madrid, Spain) equipped with a $4.0 \mathrm{~mm}$ in diameter probe with a travel distance and time of $30 \mathrm{~mm} \cdot \mathrm{min}^{-1}$ and to a depth of $3 \mathrm{~mm}$. Firmness was expressed in Newtons (N).

Total Soluble Solids. Total soluble solids (TSS) were determined by measuring the refraction index with a handheld refractometer (Atago N1, Tokyo, Japan). The refractive index was recorded and expressed as percentages. Measurements were performed at $20^{\circ} \mathrm{C}$.

These physical parameters were measured using 5 dates from each replicate and 3 replicates for treatment.

(2) Chemical Measurements. Pitted date fruits were flashfrozen in liquid nitrogen and stored at $-80^{\circ} \mathrm{C}$ for a maximum of two months and ground to a fine powder in a Cryomill in liquid nitrogen for use in the determination of chemical qualities.

Main Free Amino Acids. One gram of date tissue powder was mixed with $6 \mathrm{~mL}$ of ultrapure water and homogenized for $1 \mathrm{~min}$ with a vortex. The mixture was then centrifuged at $3,000 \times \mathrm{g}$ for $10 \mathrm{~min}$ at $4^{\circ} \mathrm{C}$ (Heraeus Fresco 21, Thermo Scientific, Germany) and filtered $(0.45 \mu \mathrm{m})$. Free amino acid analysis was performed as reported by Özcan and Şenyuva [18], by using HPLC with a UV-Vis detector (Water 2695, Photodiode array, wavelength 190 to 320 Alliance, Singapore) and mass detector (Waters Zq 4000 $(\mathrm{m} / \mathrm{z}$ from 70 to 300$)$. The chromatographic separations were performed with a Luna ${ }^{\circledR} \mathrm{C}-18$ column $(100 \AA$, $5 \mu \mathrm{m}$, $30 \times 2 \mathrm{~mm}$, Phenomenex) using the isocratic mixture of $0.01 \mathrm{mM}$ acetic acid in a $0.2 \%$ aqueous solution of formic acid at $12 \mathrm{~mL} / \mathrm{h}$. The main individual amino acids, arginine, proline, alanine, methionine, glutamic, and aspartic acid, were quantified using their respective standards, and the results were expressed as $\mathrm{mg} \cdot \mathrm{kg}^{-1}$ of fresh weight.
Composition and Concentration of Sugars. Sugar composition was determined from the same extract used for amino acid analysis. Glucose, fructose, and sucrose contents were measured by ion chromatography (IC, Metrohm 871 Advance Bioscan, Herisau, Switzerland) with a pulsed amperometric detection (PAD) detector, using an anionexchange column (1-150 Metrosep-Carb) and isocratic conditions. The operating conditions reported by Ben-Amor et al. [19] for performance liquid chromatography were used, with minor modifications (mobile phase was $\mathrm{NaOH} 80 \mathrm{mM}$, at $60 \mathrm{~mL} / \mathrm{h}$ flow rate). Individual sugars were quantified using their respective standards, and the results were expressed as $\mathrm{g} \cdot \mathrm{kg}^{-1}$ of fresh weight.

Antioxidant Activity. Two methods were used to evaluate antioxidant activity: the ferric reducing ability of plasma (FRAP) assay and the free radical scavenging activity (2,2diphenyl-1-picrylhydrazyl, DPPH) assay [20]. The extracts were prepared as follows: $1 \mathrm{~g}$ of frozen, ground date fruit was mixed with $10 \mathrm{~mL}$ methanol-water $(1: 1)$ and then maintained for $1 \mathrm{~h}$ at $200 \times \mathrm{g}$ in darkness inside a polystyrene box filled with ice. Equipment and measurements are reported by Ben-Amor et al. [19]. Calibration curves were made for each assay using ascorbic acid (AA) as standard. The antioxidant activity was expressed as $\mathrm{g}$ of ascorbic-acid equivalents (AAE) antioxidant activity per $\mathrm{kg}$ fresh weight of date tissue.

Total Phenolic Content (TPC). This assay was performed using the Folin-Ciocalteu reagent. Briefly, an aliquot of 17.2 $\mu \mathrm{L}$ extract of the supernatant was mixed with $30 \mu \mathrm{L}$ of Folin-Ciocalteu reagent $(1: 10, \mathrm{v} / \mathrm{v}$ diluted with MilliQ water) and $193 \mu \mathrm{L}$ sodium carbonate $(20 \%$, w/v). The mixture was incubated for $40 \mathrm{~min}$ at room temperature in darkness, after which the absorption was measured at $750 \mathrm{~nm}$. Total phenols were quantified using gallic acid (GA) as the standard and expressed as gallic acid equivalents (GAE) per kg fresh weight.

Three replicates for treatment were measured for each chemical parameter. For antioxidant and phenolic assays, each repetition was carried out in triplicate.

(3) Microbiological Analysis. Date fruits were pitted aseptically using sterile forceps and scalpels. Three randomized samples from each treatment containing ten grams of date fruits were aseptically placed in a sterile stomacher bag and mixed with $90 \mathrm{~mL}$ of sterile tryptone-phosphate water ( $\mathrm{pH}$ 7.0) by using a masticator (Seward Medical, London, UK). Serial dilutions were prepared in tryptonephosphate water. Type of agar and incubation conditions are reported by Ben Amor et al. [19]. Microbial counts were expressed as $\log _{10} \mathrm{cfu} / \mathrm{g}$ (colony forming units per gram of sample).

(4) Sensory Evaluation. Sensory analyses of samples from each sampling day were performed according to Ben Ismail et al. [20]. The panel consisted of eight individuals aged 25-40, from the Food Engineering Department at the Technical University of Cartagena, who had been previously screened for sensory ability (Table 2). 
TABLE 2: Guide of sensory evaluation for date fruits.

\begin{tabular}{|c|c|c|c|c|c|}
\hline $\begin{array}{l}\text { Score for } \\
\text { quality } \\
\text { level }\end{array}$ & 1 & 2 & 3 & 4 & 5 \\
\hline Color & $\begin{array}{l}\text { Very dark/very } \\
\text { yellow }\end{array}$ & $\begin{array}{l}\text { Dark brown/ } \\
\text { yellowish brown }\end{array}$ & No uniform brown & $\begin{array}{l}\text { Caramelized } \\
\text { brown }\end{array}$ & $\begin{array}{l}\text { Translucent brown uniform } \\
\text { and bright color }\end{array}$ \\
\hline Texture & $\begin{array}{l}\text { Very soft, deformed, } \\
\text { and glued/very } \\
\text { firm and wrinkled }\end{array}$ & $\begin{array}{l}\text { Quite soft, skin } \\
\text { separated from } \\
\text { pulp, and sticky }\end{array}$ & Soft but keeps its shape & Uniform firmness & $\begin{array}{l}\text { Firmness uniform with its } \\
\text { original shape when gently } \\
\text { pressed with your fingers, } \\
\text { not too dry, not too sticky }\end{array}$ \\
\hline Flavor & $\begin{array}{l}\text { High acidity/high } \\
\text { fermentation/ } \\
\text { bitterness }\end{array}$ & $\begin{array}{l}\text { Slightly acid/ } \\
\text { fermented, strange taste }\end{array}$ & $\begin{array}{l}\text { Sweet just enough } \\
\text { without foreign } \\
\text { flavors }\end{array}$ & Sufficiently sweet & $\begin{array}{l}\text { High perception } \\
\text { of sweetness }\end{array}$ \\
\hline $\begin{array}{l}\text { Overall } \\
\text { quality }\end{array}$ & Extremely poor & Poor & $\begin{array}{l}\text { Acceptable and } \\
\text { limit of usability }\end{array}$ & Good & Excellent \\
\hline
\end{tabular}

2.3.3. Statistical Analysis. For the quality experiment, a oneway analysis of variance (ANOVA, $p<0.05$ ) was carried out (Statgraphic Plus, version 5.1, 2001, Manugistic Inc, Rockville, MD, USA). Mean values were compared using an LSD test when significant differences among treatments were found.

\section{Results and Discussion}

3.1. Experiment 1: Effect of Freezing Treatment on Ectomyelois ceratoniae Mortality. Table 1 shows the effect of different freezing treatments at $-18^{\circ} \mathrm{C}(50,77$ and $125 \mathrm{~h})$ on the different stages of E. ceratoniae (young instars, old instars, and pupae). Results showed that all freezing treatments used in this experiment resulted in $100 \%$ mortality of all the development stages of E. ceratoniae. Therefore, as $50 \mathrm{~h}$ was enough time required to kill the E. ceratoniae, this treatment was selected to study the effects of a freezing treatment on the quality of the Deglet Noor palm date fruit variety.

Other studies using freezing treatments have shown that temperatures lower than $0^{\circ} \mathrm{C}$ were able to achieve significant mortality of various insects at different growth stages. Boardman et al. [21] reported that the larvae of the false codling moth, Thaumatotobia leucotreta, were killed by brief exposures to temperatures between $-8^{\circ} \mathrm{C}$ and $-12^{\circ} \mathrm{C}$. Mullen and Arbogast [22] showed that, at $-5^{\circ} \mathrm{C}, 50 \%$ of Tribolium castaneum eggs survived for 0.3 days. Studies with the related species Tribolium confusum showed that $50 \%$ of the eggs exposed to $6^{\circ} \mathrm{C}$ survived for 0.2 days [23]. In this context, Johnson and Valero [24] conducted studies in a commercial freezer set at $-18^{\circ} \mathrm{C}$ to examine the effects of freezing on the disinfestation of different life stages of the cowpea weevil, Callosobruchus maculatus (F.) present in bulk-stored garbanzo beans and reported that egg mortality was estimated to be $>98 \%$ after just $7 \mathrm{~d}$ of exposure, and complete mortality of eggs occurred after $14 \mathrm{~d}$ of frozen storage, with the egg stage being the most tolerant to $-18^{\circ} \mathrm{C}$ and the adults being most susceptible at this temperature. Similar results were obtained by Flinn et al. [25] reporting that treating flour pallets in commercial freezers for 5.5 days at $-17.8^{\circ} \mathrm{C}$ was a feasible method for achieving $100 \%$ mortality of T. castaneum eggs. Other techniques such as hot water treatment $\left(50^{\circ} \mathrm{C}\right.$ for $10 \mathrm{~min}, 55^{\circ} \mathrm{C}$ for $5 \mathrm{~min}$ and $60^{\circ} \mathrm{C}$ for $3 \mathrm{~min}$ ) [19] and hot air (at $55^{\circ} \mathrm{C}$ for $30 \mathrm{~min}, 60^{\circ} \mathrm{C}$ for $20 \mathrm{~min}$ and $60^{\circ} \mathrm{C}$ for $15 \mathrm{~min}$ ) have also obtained $100 \%$ mortality E. ceratoniae larvae [26].

\subsection{Experiment 2: Overall Date Fruit Quality after Treating} with the Temperature That Caused 100\% Mortality of Ectomyelois ceratoniae. In this second experiment, the freezing treatment of $50 \mathrm{~h}$ at $-18^{\circ} \mathrm{C}$ was used as this was the shortest treatment time that effectively caused $100 \%$ E. ceratoniae mortality in infested date fruits.

3.2.1. Physical Parameters. Color. All samples had a similar color $\left(h^{\circ}\right)$ without significant differences between treatments (Table 3). However, control and frozen dates suffered a similar and significant reduction of $L^{*}$ and Chroma. These luminosity and saturation changes led to a darker skin color. In agreement with our results, Garden-Robinson [27] indicated that some fruits such as peaches, apples, pears, and apricots darken quickly after freezing. The color changes could be attributed to the oxidized chemical compounds formed following freezing, such as water-soluble polyphenols [28]. It is well known that polyphenol compounds are more sensitive to enzymatic browning reactions, thus explaining the pronounced color changes (to brown) observed in frozen date fruit [29].

Firmness. This is one of the main quality parameters used in sensory acceptance of date fruits by the consumers. Fruit firmness increased in frozen and control date fruits (Table 3). The quality demanded in frozen fruit products is mostly based on the intended use of the product. If the fruit is to be eaten without any further processing after thawing, texture characteristics are more important when compared to its use as a raw material in other industries [15]. This increase of firmness in palm date fruit was previously described by Abboudi and Thompson [30] who showed that dates stored at $0^{\circ} \mathrm{C}$ had a lower textural firmness than dates stored at $-10^{\circ} \mathrm{C}$ and $-20^{\circ} \mathrm{C}$, and that might have been caused by the higher enzymatic activity at elevated temperatures. On the other hand, Afoakwa and Sefa-Dedeh [31] indicated that the content of plant cell wall polysaccharide constituents had a high positive correlation with firmness of the samples. The main reason for the change of firmness of date fruits during 
TABle 3: Physicochemical parameters and overall quality of Deglet Noor date fruits on control or frozen treatment.

\begin{tabular}{lccc}
\hline Parameter & Initial & Control & Frozen \\
\hline$L^{*}$ & $3 \mathrm{a}$ & $31.07 \mathrm{~b}$ & $29.87 \mathrm{~b}$ \\
$h^{\circ}$ & $65.92 \mathrm{a}$ & $65.88 \mathrm{a}$ & $63.32 \mathrm{a}$ \\
Chroma & $19.25 \mathrm{a}$ & $12.81 \mathrm{~b}$ & $12.95 \mathrm{~b}$ \\
Firmness $(N)$ & $9.76 \mathrm{~b}$ & $11.78 \mathrm{a}$ & $13.51 \mathrm{a}$ \\
TSS $(\%)$ & $58.33 \mathrm{a}$ & $62.33 \mathrm{a}$ & $57.67 \mathrm{a}$ \\
Alanine & $5.43 \mathrm{a}$ & $4.48 \mathrm{a}$ & $4.45 \mathrm{a}$ \\
Arginine & $4.26 \mathrm{a}$ & $4.16 \mathrm{a}$ & $3.81 \mathrm{a}$ \\
Aspartic acid & $7.66 \mathrm{a}$ & $7.10 \mathrm{a}$ & $8.64 \mathrm{a}$ \\
Glutamic acid & $8.54 \mathrm{a}$ & $8.38 \mathrm{a}$ & $8.85 \mathrm{a}$ \\
Methionine & $10.21 \mathrm{a}$ & $9.82 \mathrm{a}$ & $9.92 \mathrm{a}$ \\
Glucose & $138.7 \mathrm{~b}$ & $160.3 \mathrm{a}$ & $162.3 \mathrm{a}$ \\
Fructose & $171.3 \mathrm{~b}$ & $196.8 \mathrm{ab}$ & $208.9 \mathrm{a}$ \\
Sucrose & $484.9 \mathrm{a}$ & $409.6 \mathrm{a}$ & $414.7 \mathrm{a}$ \\
Total sugars & $794.9 \mathrm{a}$ & $778.9 \mathrm{a}$ & $773.8 \mathrm{a}$ \\
FRAP & $1.09 \mathrm{a}$ & $1.01 \mathrm{a}$ & $0.67 \mathrm{~b}$ \\
DPPH & $0.86 \mathrm{a}$ & $0.82 \mathrm{a}$ & $0.48 \mathrm{~b}$ \\
TPC & $0.96 \mathrm{a}$ & $0.84 \mathrm{a}$ & $0.81 \mathrm{a}$ \\
OQ & $3.65 \mathrm{a}$ & $3.60 \mathrm{a}$ & $3.30 \mathrm{a}$ \\
\hline
\end{tabular}

Means $(n=3)$ within the same row with different letters are significantly different ( $p \leq 0.05)$ according to the LSD test. TSS: total soluble solids; OQ: overall quality (Table 2). Individual free amino acids are expressed as $\mathrm{mg} \cdot \mathrm{kg}^{-1}$, individual sugar contents as $\mathrm{g} \cdot \mathrm{kg}^{-1}$, and antioxidant content (FRAP and DPPH) and total phenolic content (TPC) as $\mathrm{g} \mathrm{kg}^{-1}$.

the storage period was probably due to the increase in cell rigidity and subsequent strengthening of cell wall bonding. Low-temperature storage could therefore be used to effectively increase the firmness of date fruits [32].

TSS. The statistical analysis showed that this parameter was unaffected by storage at room temperature or freezing treatment, and all of samples had a similar range of ${ }^{\circ} \mathrm{Brix}$, ranging from 57 to 62 (Table 3). This unchanged TSS was probably due to the harvesting of palm date fruit at the full maturity stage (Tamar), which is characterized by having the maximum TSS content [33].

3.2.2. Chemical Measurements. Main Free Amino Acids. Sulieman et al. [34] reported that the date palm extract contains high amounts of essential amino acids, indicating that dates have a high nutritional value. The free amino acids analysis results are shown in Table 3, and they indicate that the freezing treatment did not affect the free amino acids contained in date palm fruit, as there were no significant differences as compared to the control treatment. Likewise, Lisiewska et al. [35] reported that the differences in the content of amino acids between raw, cooked, and frozen seeds were insignificant on broad bean seeds.

Composition and Concentration of Sugars. Date fruit is unique in relation to freezing treatments, as it has a very high sugar content. Freezing characteristics, such as freeze-thaw temperatures, ice crystal growth, freeze-concentration, and freeze-drying, are functions of solute concentration [36]. The sugar analysis on date fruit showed that they are rich in glucose, fructose, and sucrose, which are easy to digest by human cells and useful for getting the energy required for metabolic processes [34]. Sucrose is one of the main sugars that is characteristic of the Deglet Noor cultivar and one of the main reasons behind the very pleasant taste of the fruit [2]. The freezing treatments increased the content of glucose and fructose as compared to day 0 , maintaining the sucrose and the total sugar content to similar levels as compared to the rest of the samples (Table 3). This increase in monosaccharides recorded during the freezing treatment was previously observed in frozen date fruits at $-20^{\circ} \mathrm{C}$ [37]. This could be due to the effect of freezing on the concentration of solutes more than the effect of invertase hydrolyzation during storage of date fruits, when the concentration of sucrose decreases as it is converted to glucose and fructose, with the concentration of these monosaccharides increasing as a consequence [38]. In agreement with our results, Chung et al. [39] reported that the freezing pretreatment can increase the glucose and fructose content in the juices extracted from Prunus mume fruit with no significant difference in sucrose content.

Antioxidant Activity. Date fruit contains different types of phenolic compounds, which have different antioxidant capacities [40]. The freezing treatment significantly reduced the antioxidant activity of the fruits samples as measured by FRAP and DPPH (Table 3). In accordance with our results, storage at $-18^{\circ} \mathrm{C}$ decreased antioxidant activities in fresh spring onions [41]. Moreover, Jeusti Bof et al. [42] observed that the antioxidant activity of pear pulp stored at $-15^{\circ} \mathrm{C}$ for 90 days resulted in a significant decrease as compared to fresh fruit. Similarly, Shofian et al. [43] reported that fresh starfruit and mango exhibited significantly higher FRAP and $\mathrm{DPPH}$ values as compared with those of freeze-dried samples at $-20^{\circ} \mathrm{C}$ for 24 hours.

Total Phenolic Content. Palm date fruit especially Deglet Noor cv. is rich in phenolic compounds [44]. Date fruit can be considered a potential natural source of bioactive phytochemicals that play major roles in human health as free radical scavengers [45]. The sample's phenolic content averages ranged from 0.81 to $0.96 \mathrm{~g} \mathrm{GAE} \mathrm{kg}^{-1}$ (Table 3). Results obtained in this study were higher than those of Algerian date varieties, 0.02 to $0.08 \mathrm{~g}$ GAE $/ \mathrm{kg} \mathrm{fw}$, as analyzed by Mansouri et al. [46]. Closer to our results, Kchaou et al. [47] showed average levels for Tunisian date varieties to be 1.6 to $2.2 \mathrm{~g} \mathrm{GAE} / \mathrm{kg}$ fw. The freezing treatment did not cause any significant changes in TPC in date fruit, as previously reported by Rickman et al. [48], who informed that freezing caused minimal destruction of phenolic compounds in fruits, with retention levels dependent on cultivar. Our results agree with those reported for raspberry [49] when fruits were stored at $-20^{\circ} \mathrm{C}$ for 12 months.

3.2.3. Microbiological Analysis. The microbial load of date samples is shown in Figure 1. The initial microbial counts for untreated samples were $2.7 \pm 0.1 \log \mathrm{cfu} \cdot \mathrm{g}^{-1}$ for mesophilic bacteria, $4.2 \pm 0.2 \log \mathrm{cfu} \cdot \mathrm{g}^{-1}$ for yeast, and $4.0 \pm 0.2 \log \mathrm{cfu} \cdot \mathrm{g}^{-1}$ for molds. These microbial counts remained virtually unchanged in both samples stored for $3 \mathrm{~d}$ at room temperature (control) and those treated for $3 \mathrm{~d}$ with the freezing treatment. Our results agree with the UNIDO report [50], which states that freezing processes are not suitable for the destruction of 


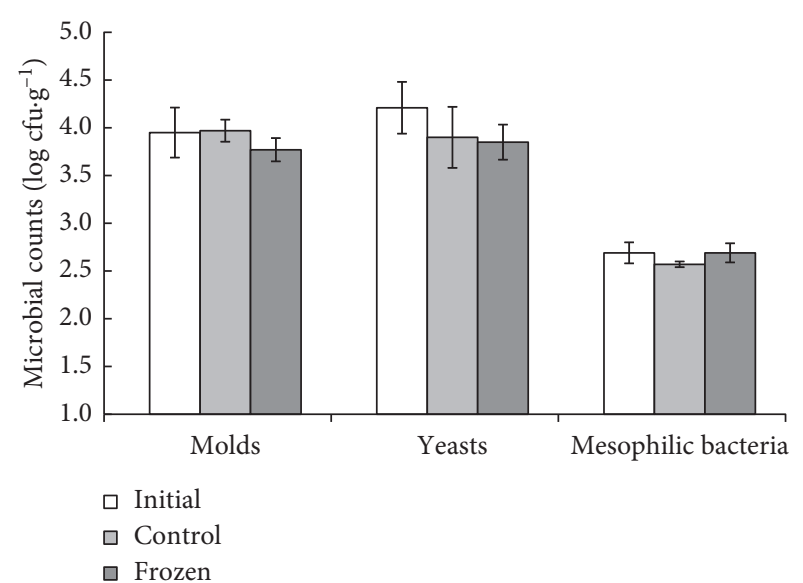

FIgURe 1: Microbial counts of Deglet Noor date fruits on control or frozen treatment. Data are expressed as means $(n=3) \pm \mathrm{SE}$.

the microorganisms present on fruits and vegetables. In this context, Garden-Robinson [27] informed that microorganisms do not grow at freezing temperatures, but most are not destroyed and will multiply as quickly as ever when the frozen food is thawed and allowed to be kept at room temperature.

3.2.4. Sensorial Analysis. Sensorial quality is an important parameter used by producers to determine shelf-life. Freezing is one of the most important methods for retaining quality during long-term storage [15]. The sensorial quality scores of palm date fruit were absolutely not affected by the freezing treatment, as all the sensorial attributes such as color, flavor, and texture remained stable (with mean scores about 3.2,3.3, and 3.8, respectively). This was also true for the overall acceptance (Table 3 ) of the fruit before as well as after treatment. These results qualify the freezing treatment as a good tool for the preservation of sensorial quality parameters. Thus, in all the samples, the sensorial parameters scores were above the limit of marketability $(>3)$. Similar overall quality results for frozen storage of raspberry fruit were reported by De Ancos et al. [49]. However, Shomer et al. [36] reported that date fruits stored at $-18^{\circ} \mathrm{C}$ for 10 months developed tissue injuries, evidenced as yellow-brown spots, pale color, and cell sap leakage. In our experiment, these chilling injuries were not seen, which was probably due to the short treatment time used.

\section{Conclusions}

All the freezing treatments studied $\left(-18^{\circ} \mathrm{C}\right.$ for $50 \mathrm{~h}, 77 \mathrm{~h}$ and $125 \mathrm{~h}$ ) lead to $100 \%$ mortality of all the stages of $E$. ceratoniae in date fruit, and these treatments can be used as an alternative tool to chemical treatments. The use of a freezing treatment of $50 \mathrm{~h}$ maintained all the physicochemical studied parameters stable, with only a significant reduction on the antioxidant activity and an increase of monosaccharides. The microbial and sensorial qualities were not affected by the freezing treatment.

\section{Data Availability}

The data (average and SE) used to support the findings of this study are included within the article (Tables 1 and 3; Figure 1). Raw data are available from the corresponding author upon request by email.

\section{Disclosure}

This manuscript is a chapter of the thesis titled "Analysis on the international competitiveness of Tunisian palm date fruit Deglet Noor cv. and studies on the effects of physical postharvest treatments on Ectomyelois ceratoniae mortality and fruit quality."

\section{Conflicts of Interest}

The authors declare that there are no conflicts of interest regarding the publication of this paper.

\section{Acknowledgments}

Rihab Ben Amor thanks the Erasmus Mundus program for the concession of a predoctoral scholarship (UE-Mare Nostrum). The authors thank all the people for their help directly and indirectly to complete their assignment.

\section{References}

[1] N. Ortiz-Uribe, R. Salomón-Torres, and R. Krueger, "Date palm status and perspective in Mexico," Agriculture, vol. 9, no. 3, p. 46, 2019.

[2] R. Ben-Amor, "Analysis on the international competitiveness of Tunisian palm date fruit Deglet Noor cv. and studies on the effects of physical postharvest treatments on Ectomyelois ceratoniae mortality and fruit quality," Directoras: Encarna Aguayo Gimenéz y María Dolores de Miguel Gómez. Tesis doctoral, Universidad Politécnica de Cartagena. Área de Tecnología de Alimento y Departamento de Economía de la Empresa, Murcia, Spain, 2016.

[3] N. Guizani, G. S. Al-Saidi, M. S. Rahman, S. Bornaz, and A. A. Al-Alawi, "State diagram of dates: glass transition, freezing curve and maximal-freeze-concentration condition," Journal of Food Engineering, vol. 99, no. 1, pp. 92-97, 2010.

[4] Z. Benmeddour, E. Mehinagic, D. Le Meurlay, and H. Louaileche, "Phenolic composition and antioxidant capacities of ten Algerian date (Phoenix dactylifera L.) cultivars: a comparative study," Journal of Functional Food, vol. 5, no. 1, pp. 346-354, 2013.

[5] M. V. Zadeh, K. Afrooz, M. Shamsi, and M. A. Rostami, "Measuring the dielectric properties of date palm fruit, date palm leaflet, and Dubas bug at radio and microwave frequency using two-port coaxial transmission/reflection line technique," Biosystems Engineering, vol. 181, pp. 73-85, 2019.

[6] FAOSTAT, "Food and agriculture organization of the United Nations. Statistical databases," 2018, http://faostat.fao.org/.

[7] M. H. Dhouibi, "Biologie et écologie d'Ectomyelois ceratoniae Zeller. (Lepidoptera: Pyralidae) dans deux biotopes différents au sud de la Tunisie et recherches de méthodes alternatives de lutte," Thèse de Doctorat d'état en Sciences Naturelles, p. 176, 1989.

[8] M. Jemni, M. Otón, J. G. Ramirez et al., "Conventional and emergent sanitizers decreased Ectomyelois ceratoniae 
infestation and maintained quality of date palm after shelflife," Postharvest Biology and Technology, vol. 87, pp. 33-41, 2014.

[9] A. Zouba, O. Khoualdia, A. Diaferia, V. Rosito, H. Bouabidi, and B. Chermiti, "Microwave treatment for postharvest control of the date moth Ectomyelois ceratoniae. Tunis," Journal of Plant Protection Research, vol. 4, pp. 173-184, 2009.

[10] H. A. Al-Kahtani, M. Hamza, Y. Abu-Tarboush et al., "Irradiation of dates: insect disinfestation, microbial and chemical assessment, and use of thermo luminescence technique," in Proceedings of the First International Conference on Date Palms, Al, Ain, UAE, March 1998.

[11] M. A. El-Mohandes, "Nonchemical methyl bromide alternatives in dates processing sector," in Dates: Production, Processing, Food and Medicinal Values, A. Manickavasagan, M. M. Essa, and E. Sukumar, Eds., pp. 227-254, CRC Press, Taylor \& Francis Group, Boca Raton, FL, USA, 2012.

[12] J. S. Bale and S. A. L. Hayward, "Insect overwintering in a changing climate," Journal of Experimental Biology, vol. 213, no. 6, pp. 980-994, 2010.

[13] B. J. Sinclair, L. E. Coello Alvarado, and L. V. Ferguson, "An invitation to measure insect cold tolerance: methods, approaches, and workflow," Journal of Thermal Biology, vol. 53, pp. 180-197, 2015.

[14] C. Vincent, G. Hallman, B. Panneton, and F. Fleurat-Lessard, "Management of agricultural insects with physical control methods," Annual Review of Entomology, vol. 48, no. 1, pp. 261-281, 2003.

[15] D. L. Denlinger and R. E. Lee, Insect Low Temperature Biology, Cambridge University Press, Cambridge, UK, 2010.

[16] G. V. Barbosa-Cánovas, B. Altunakar, and D. J. Mejía-Lorío, "Freezing of fruits and vegetables. An agribusiness alternative for rural and semi-rural areas," in FAO Agricultural Services Bulletin No. 158, p. 76, Food and Agriculture Organization of the United Nations, Rome, Italy, 2005.

[17] A. A. Kader and A. M. Hussein, Harvesting and Postharvest Handling of Dates, ICARDA, Aleppo, Syria, 2009.

[18] S. Özcan and H. Z. Şenyuva, "Improved and simplified liquid chromatography/atmospheric pressure chemical ionization mass spectrometry method for the analysis of underivatized free amino acids in various foods," Journal of Chromatography A, vol. 1135, no. 2, pp. 179-185, 2006.

[19] R. Ben-Amor, M. H. Dhouibi, and E. Aguayo, "Hot water treatments combined with cold storage as a tool for Ectomyelois ceratoniae mortality and maintenance of Deglet Noor palm date quality," Postharvest Biology and Technology, vol. 112, pp. 247-255, 2016.

[20] H. Ben Ismaïl, N. Djendoubi, A. Kodia, D. Ben Hassine, and M. Ben Slama, "Physicochemical characterization and sensory profile of 7 principal Tunisian date cultivars," Emirates Journal of Food and Agriculture, vol. 25, no. 5, pp. 331-341, 2013.

[21] L. Boardman, T. G. Grout, and J. S. Terblanche, "False codling moth Thaumatotibia leucotreta (Lepidoptera, Tortricidae) larvae are chill-susceptible," Insect Science, vol. 19, no. 3, pp. 315-328, 2012.

[22] M. A. Mullen and R. T. Arbogast, "Time-temperaturemortality relationships for various stored-product insect eggs and chilling times for selected commodities," Journal of Economic Entomology, vol. 72, no. 4, pp. 476-478, 1979.

[23] R. H. Nagel and H. H. Shepard, "The lethal effect of low temperatures on the various stages of the confused flour beetle," Journal of Agricultural Research, vol. 48, pp. 10091016, 1934.
[24] J. A. Johnson and K. A. Valero, "Use of commercial freezers to control cowpea weevil, Callosobruchus maculatus (Coleoptera: Bruchidae), in Organic Garbanzo Beans," Journal of Economic Entomology, vol. 96, no. 6, pp. 1952-1957, 2003.

[25] P. W. Flinn, F. H. Arthur, J. E. Throne, K. S. Friesen, and K. L. Hartzer, "Cold temperature disinfestation of bagged flour," Journal of Stored Products Research, vol. 63, pp. 42-46, 2015.

[26] R. Ben Amor, M. D. de Miguel-Gómez, A. Martínez-Sánchez, and E. Aguayo, "Effect of hot air on Deglet Noor palm quality parameters and on Ectomyelois ceratoniae," Journal of Stored Products Research, vol. 68, pp. 1-8, 2016.

[27] J. Garden-Robinson, Food Freezing Guide, Revised Edition, NDSU, Fargo, ND, USA, 2013.

[28] G. Skrede, "Fruits," in Freezing Effects on Food Quality, L. E. Jeremiah, Ed., pp. 183-245, Marcel Dekker Inc., New York, NY, USA, 1996.

[29] S. Chassagne-Berces, F. Fonseca, M. Citeau, and M. Marin, "Freezing protocol effect on quality properties of fruit tissue according to the fruit, the variety and the stage of maturity," LWT-Food Science and Technology, vol. 43, no. 9, pp. 14411449, 2010.

[30] A. H. Abboudi and A. K. Thompson, "Effect of temperature on the storage of Rutab dates harvested at different maturity stages," in Proceedings of the Date Palm Conference, United Arab Emirates University Faculty of Agricultural Sciences, AlAin, UAE, March 1998.

[31] E. O. Afoakwa and S. Sefa-Dedeh, "Chemical composition and quality changes occurring in Dioscorea dumetorum pax tubers after harvest," Food Chemistry, vol. 75, no. 1, pp. 85-91, 2001.

[32] S. M. Aleid, A. M. Elansari, T. Zhen-Xing, and A. A. Sallam, "Effect of cold storage and packing type on Khalas and Sukkary dates quality," Advance Journal of Food Science and Technology, vol. 6, no. 5, pp. 603-608, 2014.

[33] I. A. Ahmed, A. W. K. Ahmed, and R. K. Robinson, "Chemical composition of date varieties as influenced by the stage of ripening," Food Chemistry, vol. 54, no. 3, pp. 305-309, 1995.

[34] A. M. E. Sulieman, I. A. Abd Elhafise, and A. M. Abdelrahim, "Comparative study on five Sudanese Date (Phoenix dactylifera L.) fruit cultivars," Food and Nutrition Sciences, vol. 3, no. 9, pp. 1245-1251, 2012.

[35] Z. Lisiewska, W. Kmiecik, and J. Slupski, "Content of amino acids in raw and frozen broad beans (Vicia faba var. major) seeds at milk maturity stage, depending on the processing method," Food Chemistry, vol. 105, no. 4, pp. 1468-1473, 2007.

[36] I. Shomer, H. Borochov-Neori, B. Luzki, and U. Merin, "Morphological, structural and membrane changes in frozen tissues of Madjhoul date (Phoenix dactylifera L.) fruits," Postharvest Biology and Technology, vol. 14, no. 2, pp. 207-215, 1998.

[37] A. Alhamdan, B. Hassan, H. Alkahtani, D. Abdelkatim, and M. Younis, "Cryogenic freezing of fresh date fruits for quality preservation during frozen storage," Journal of the Saudi Society of Agricultural Sciences, vol. 17, no. 1, pp. 9-16, 2018.

[38] W. M. Chang, Y. T. Chen, and C. C. Shu, "The browning factors and analysis of browning speed in mei syrup during storage," Food Preservation Science, vol. 24, no. 2, pp. 87-93, 1998.

[39] H. S. Chung, D. S. Kim, H. S. Kim, Y. G. Lee, and J. H. Seong, "Effect of freezing pretreatment on the quality of juice extracted from Prunus mume fruit by osmosis with sucrose," LWT-Food Science and Technology, vol. 54, no. 1, pp. 30-34, 2013. 
[40] E. D. T. Bouhlali, M. Ramchoun, C. Alem, K. Ghafoor, J. Ennassir, and Y. Filali Zegzouti, "Functional composition and antioxidant activities of eight Moroccan date fruit varieties (Phoenix dactylifera L.)," Journal of the Saudi Society of Agricultural Sciences, vol. 16, no. 3, pp. 257-264, 2017.

[41] E. M. El-Hadidy, M. E. A. Mossa, and H. N. Habashy, "Effect of freezing on the pungency and antioxidants activity in leaves and bulbs of green onion in Giza 6 and Photon varieties," Annals of Agricultural Sciences, vol. 59, no. 1, pp. 33-39, 2014.

[42] C. M. Jeusti Bof, R. C. Fontana, L. T. Piemolini-Barreto, and I. G. Sandri, "Effect of freezing and processing technologies on the antioxidant capacity of fruit pulp and jelly," Brazilian Archives of Biology and Technology, vol. 55, no. 1, pp. 107-114, 2012.

[43] N. M. Shofian, A. A. Hamid, A. Osman et al., "Effect of freezedrying on the antioxidant compounds and antioxidant activity of selected tropical fruits," International Journal of Molecular Sciences, vol. 12, no. 7, pp. 4678-4692, 2011.

[44] S. Mathew, A. Halama, S. Abdul Kadera et al., "Metabolic changes of the blood metabolome after a date fruit challenge," Journal of Functional Foods, vol. 49, pp. 267-276, 2018.

[45] H. Louaileche, D. Hammiche, and F. Hamoudi, "Total phenolic, flavonoid contents and in vitro antioxidant activity of Algerian date palm varieties: a comparative study," American Journal of Food Science and Health, vol. 1, no. 3, pp. 63-68, 2015.

[46] A. Mansouri, G. Embarek, E. Kokkalou, and P. Kefalas, "Phenolic profile and antioxidant activity of the Algerian ripe date palm fruit (Phoenix dactylifera)," Food Chemistry, vol. 89, no. 3, pp. 411-420, 2005.

[47] W. Kchaou, F. Abbès, B. Blecker, H. Attia, and S. Besbes, "Effects of extraction solvents on phenolic contents and antioxidant activities of Tunisian date varieties (Phoenix dactylifera L.)," Industrial Crops and Products, vol. 45, pp. 262-269, 2013.

[48] J. C. Rickman, D. M. Barrett, and C. M. Bruhn, "Nutritional comparison of fresh, frozen and canned fruits and vegetables. Part 1. Vitamins C and B and phenolic compounds," Journal of Science Food and Agriculture, vol. 87, no. 6, pp. 930-944, 2007.

[49] B. De Ancos, E. Ibañez, G. Reglero, and M. P. Cano, "Frozen storage effects on anthocyanins and volatile compounds of raspberry fruit," Journal of Agricultural and Food Chemistry, vol. 48, pp. 873-879, 2000.

[50] UNIDO Reports, Freezing Methods and Quality Loss at Freezing Temperatures, III UNISWORK Food Safety Programme, United Nations Industrial Development Organization (UNIDO), Vienna International Centre, Vienna, Austria, 2004. 


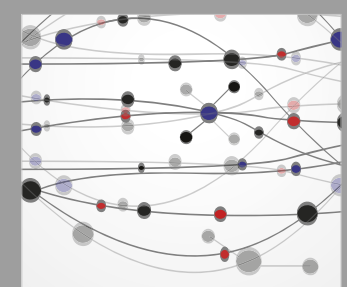

The Scientific World Journal
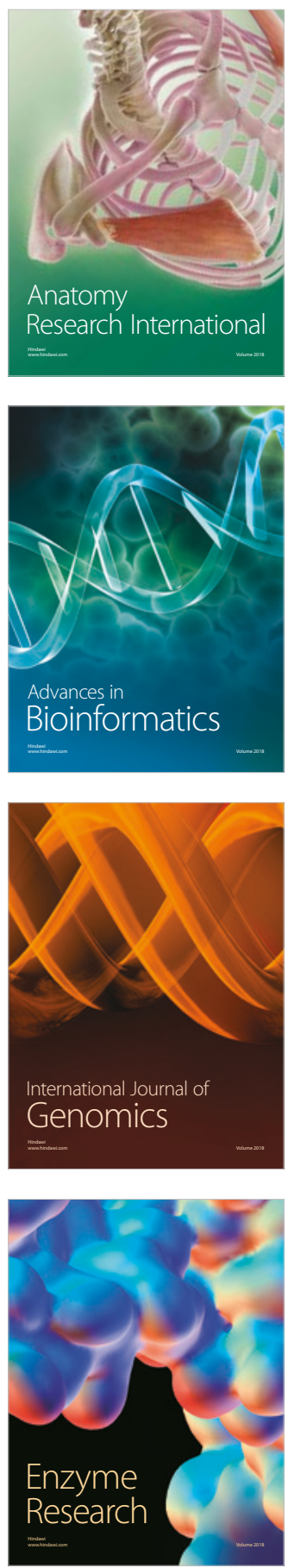
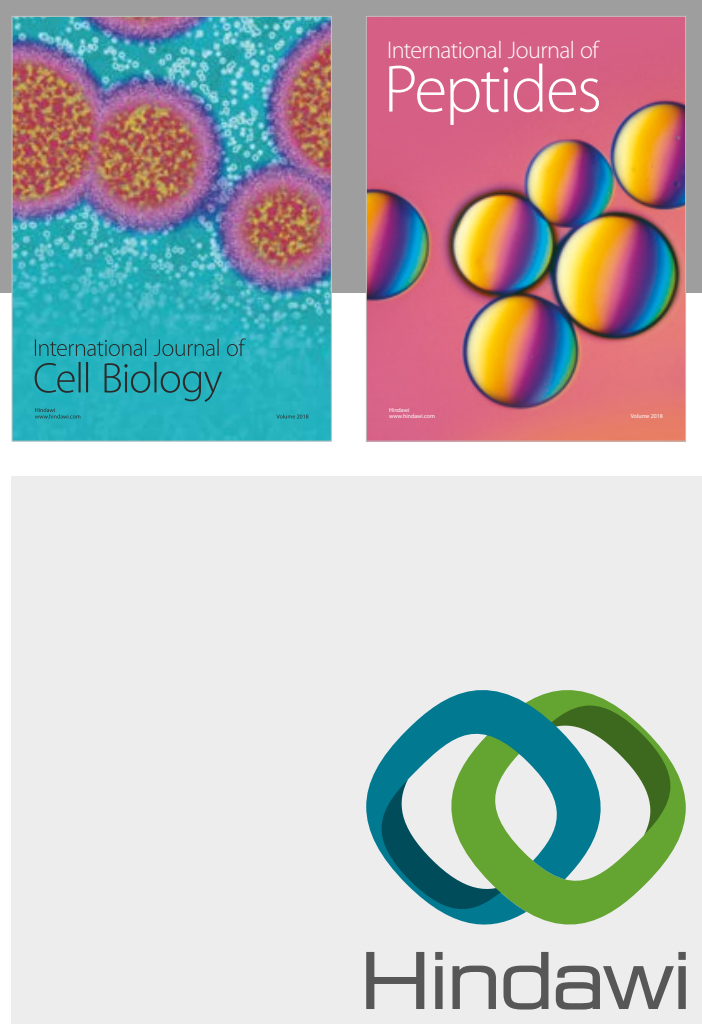

Submit your manuscripts at

www.hindawi.com
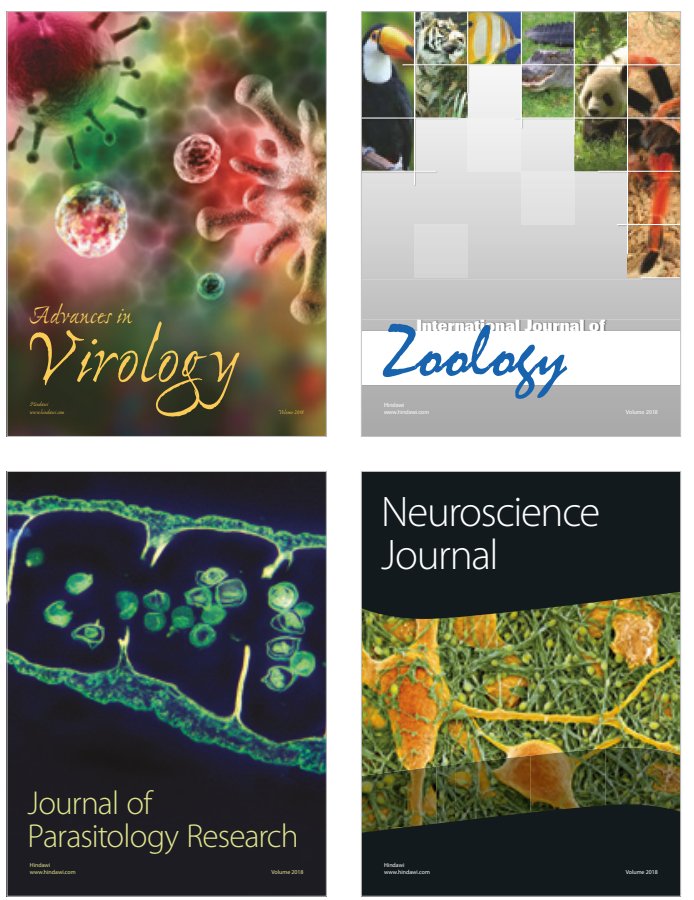
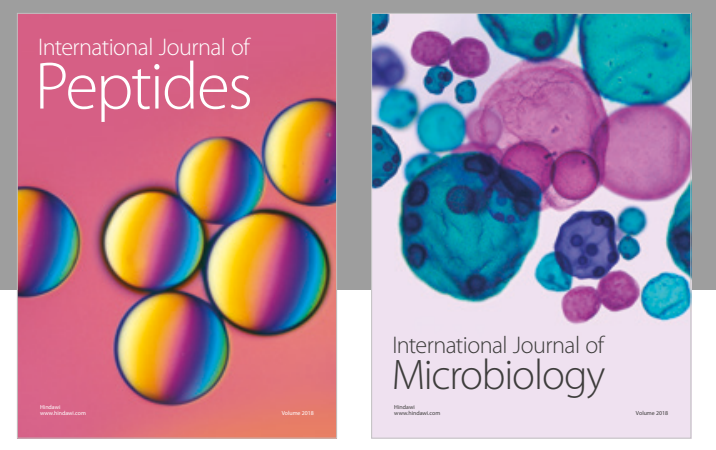

nternational Journal of Microbiology
Journal of
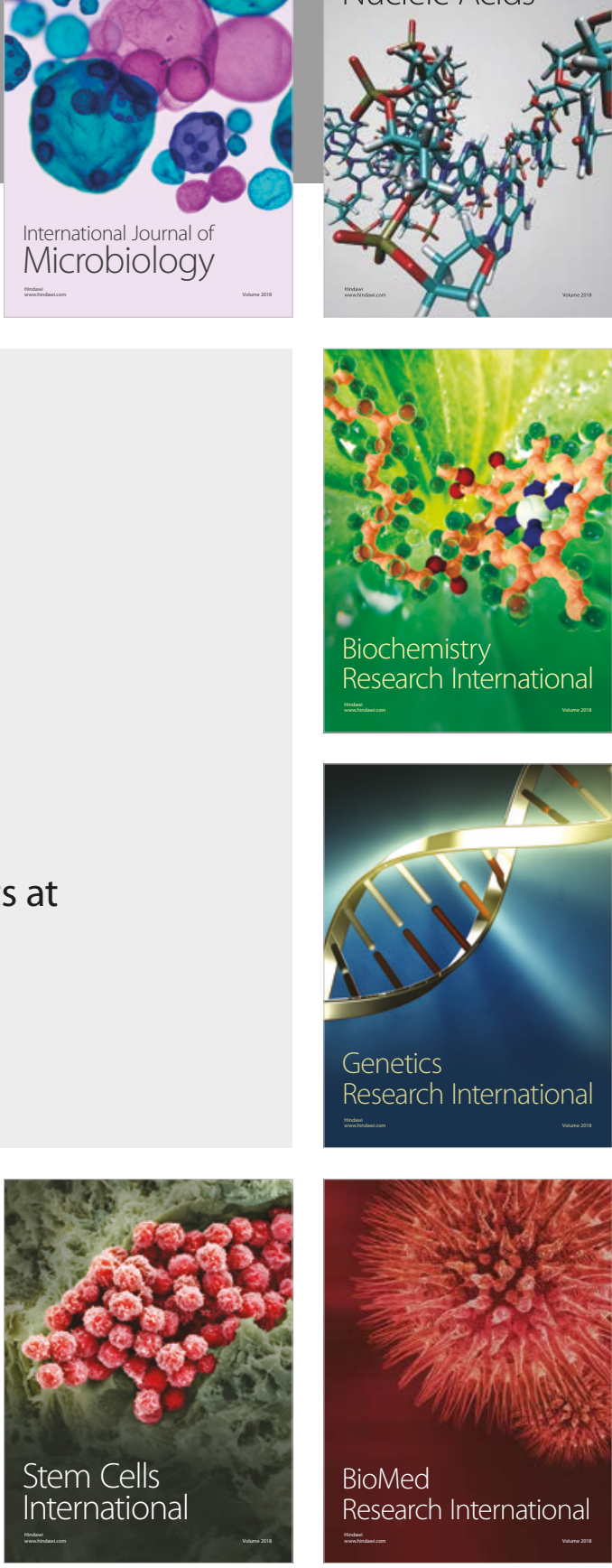
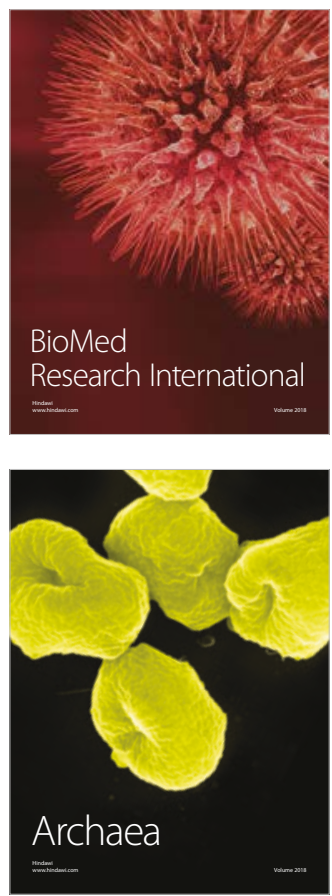